Scientific Journal Warsaw University of Life Sciences - SGGW

Problems of World Agriculture volume 18 (XXXIII), number 2, 2018: 270-279

DOI: 10.22630/PRS.2018.18.2.54

Devesh Singh $^{1}$, Zoltán Gál ${ }^{2}$, Raqif Huseynov ${ }^{3}$, Michal Wojtaszek ${ }^{4}$

${ }_{1,2}$ Kaposvár University, Hungary

${ }^{3}$ Szent István University, Gödöllő, Hungary

${ }^{4}$ Warsaw University of Life Sciences - SGGW, Poland

\title{
Determining the Performance Measurement of SME from Economic Value Added: Study on Hungary, Somogy County
}

\begin{abstract}
EVA (Economic Value Added) permits commercial businesses to figure out whether the business is operating in profit and the money can be put into effect into a more profitable source. A leading EVA is a sign that the company has a greater value. The goal of this study is to identify if SMEs' actions carried out on a daily basis are able to generate economic value added for their business. The study is based on a comparative study between Hungary and 28 EU countries. The study is carried out in Hungary's region of Somogy county. First, the variables for research were created and research was carried out at ground level. The research used the Expletory Factor analysis method to find EVA determinants. The results showed that determinants work together to reshape the regional industrial growth. The research demonstrated that finance and sluggish production are the major determinants in Somogy county. Entrepreneurs' skills and finance have the major impact, which means that to achieve a high growth in SMEs, policy makers have to solve these two problems and make the policy concentric toward finance and high skill development problem.
\end{abstract}

Keywords: Economic value added, small and medium-sized enterprises SMEs, performance measurement, Hungary, Somogy County

JEL Classification: L26, F64, G32

\section{Introduction}

Small and medium-sized enterprises are the core of industrial development. They are essential for both developed and developing countries. Small and medium-sized enterprises have always represented the model of economic development indicating a substantial contribution to domestic production, considerable export earnings, low investment requirements, the generation of workplaces, and the effective improvement of foreign exchange income of the nation with low import-intensive operations.

The concept of economic value added (EVA) started to originate when Hamilton (1877) and Marshall (1890) perceived that companies can create profit if they earn more than their own capital cost and liabilities. EVA is used to measure the performance of a company; it is an indicator of how well the firm is performing and gives investors the opportunity to analyze the company's condition (Petrescu \& Apostol, 2009, p. 1).

\footnotetext{
${ }^{1}$ MA, PhD student, Faculty of Economics, Kaposvár University, Kaposvár, 7400, Hungary, e-mail: dev.singh.ece@gmail.com

${ }^{2}$ Dr., Department of Regional Economics \& Statistics, Kaposvár University, Kaposvár, 7400, Hungary

${ }^{3}$ MA, PhD student, Enyedi György Doctoral School of Regional Sciences, Szent István University, Gödöllö, e-mail: raqif_h@yahoo.de

${ }^{4} \mathrm{MA}, \mathrm{PhD}$ student, Department of Agricultural Economics and International Economic Relations WULS-SGGW, 166 Nowoursynowska St., 02-787 Warszawa, e-mail: michal_wojtaszek@sggw.pl; https://orcid.org/0000 $00025173-8457$
} 
Nowadays, EVA is a management consulting tool developed by Stern Value Management, which owns the trademark of EVA ${ }^{\mathrm{TM}}$. Stern Value Management started to originate in the 1950s. In 1983, it developed EVA to maximize the firm's value creation. EVA expresses business performance. EVA has different fundamental requirements, a different view on management decisions considering the cost capital and the approach toward value creation for the shareholder (Daraban Marius Costin, 2017). There are very few studies available supporting the empirical validity of the performance management tool. For advanced economies, the EVA concept has noticeable significance, but validity and implementation are debatable. In advanced economies, EVA is an important performance measurement and management tool. EVA has superiority over other management tools (Sharma \& Kumar, 2010, p. 1).

EVA provides facilitation as an investment decision monitoring tool which is applicable to the staff level, to the corporate level. In organizations, EVA can be used to create shareholder value by stretching the positive product spread with the multiplication of capital employed. This approach results in minimizing the capital tied for operation (Girotra \& Yadav, 2001). EVA is an overall performance indicator instead of one applicable per company employee. In EVA, sales management is the main feature of the firm's inclusive performance and it has direct impact on customer satisfaction (Norton, 1992, p. 77). EVA adaptation as performance is very challenging in the United States of America. In recent years, the concept of EVA appeared in many other countries and is vastly used in Brazil, the UK, Germany, Australia, France, Canada and Mexico (Günther at al, 2000; Worthington and West, 2001). EVA was analysed on Germany's stock market and the results demonstrated that EPS is better than EVA for predicting the future performance and differences across the company.

Small and medium-sized enterprises (SMEs) are the chief support of Europe's economy. They comprise $99 \%$ of all businesses in the EU. In the past five years, they have brought into existence around $85 \%$ of new jobs and made available two-thirds of the whole private sector employment in the EU. The European Commission (EC) considers SMEs and entrepreneurship a decisive factor in economic growth, innovation, job creation, and social integration in the EU. Hungary's SME sector has an important position as far as employment is concerned. SMEs have the largest stake in terms of the number of enterprises, employment and value-added compared to the EU mainstream. Consequently, the average Hungarian SME is smaller - at least in employment terms - compared to the rest of the EU.

This research attempts to identify the strategies that can generate value for companies. After this, we try to examine different scientific points of view. Next, we try to generate a Likert scale investigating which factor can influence the company's economic value.

\section{Literature Review}

The definition of an SME is significant for access to finance and EU support programmes aimed specifically at such enterprises. Depending on the country, the size of the enterprise can be categorized based on the number of employees, annual sales, assets, or any combination of these. Small to medium enterprises (SMEs) make up the vast majority of businesses in most countries. A business with a headcount of fewer than 250 is classified 
as medium-sized; a business with a headcount of fewer than 50 is classified as small, and a business with a headcount of fewer than 10 is considered a micro-business.

Table 1. EU definition of SMEs

\begin{tabular}{l|ccc}
\hline \multicolumn{1}{c|}{ Category } & Employees & Turnover & Balance sheet total \\
\hline Micro & $<10$ & $<€ 2$ million & $<€ 2$ million \\
Small & $<50$ & $<€ 10$ million & $<€ 10$ million \\
Medium -sized & $<250$ & $<€ 50$ million & $<€ 43$ million \\
\hline
\end{tabular}

Source: Commission Recommendation of 6 May 2003 concerning the definition of micro, small, and mediumsized enterprises. (2003/361/EC), Official Journal of the European Union, L 124/36, 20 May 2003.

In 2018, the European Union revised the SME definition and announced an open public consultation on the official European Union's website. In the Eurostat database, SMEs are described on the basis of staff head count and the total turnover. In general, they are businesses which employ fewer than 250 staff and have an annual turnover of less than EUR 50 million.

There are very few performance measurement tools applicable to SMEs overall performance because SMEs are the sector which is limited by the resources and lack of managerial skills (Garengo et al., 2005). SMEs do not have the compared standard expertise to implement sophisticated and complex performance measurement systems and employ them successfully (Laitinen, 1996; Hussein et al., 1998). EVA contains all financial information from the income statement and contains all balance sheet components. EVA considers all resources, cost and profit generated from these resources (Young and O'Byrne, 2001, p. 5). EVA provides a platform that integrates operational and financial components on a single platform with a reassembling effect (Stern et al., 1998, p. 484).

EVA contains assets, operations, finance and sales. EVA measures all components, customers, internal processes, financial measures and learning but does not explain how these components are combined together and help to measure the global performance (Kaplan and Norton, 1992).

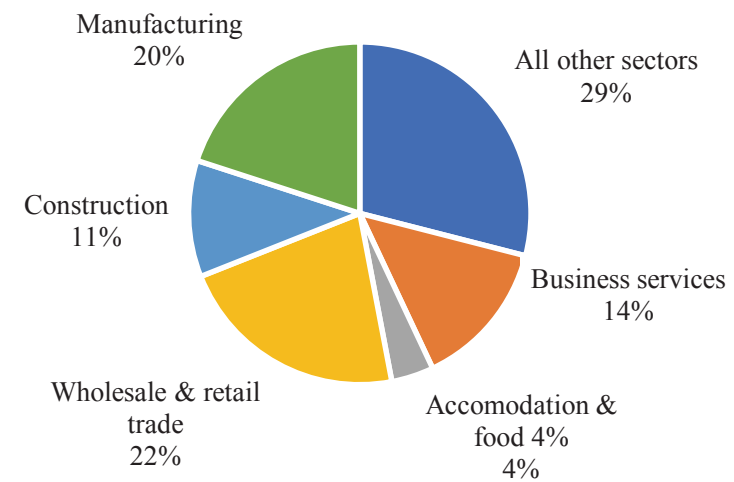

Fig. 1. Breakdown of SME value added in 2015 by main sector, EU28

Source: Annual report Europe's SMEs 2015. 
Wholesale, retail goods, and services contributed more to SMEs. Manufacturing represented $20 \%$ of the total participation. For the first time since the recession, SME employment grew in 2014 (1.1\%). In 2015, SME employment increased by 1.5\%. Indeed, following a number of years of poor economic performance, in 2015 EU28 SMEs experienced good growth in value added for the second year in a row $(3.8 \%$ in 2014 and $5.7 \%$ in 2015). According to the EU 28 review analysis from 2016, 99 out of every 100 businesses are SMEs. SMEs employ two out of every three employees and produce 57 cents of every euro in value added.

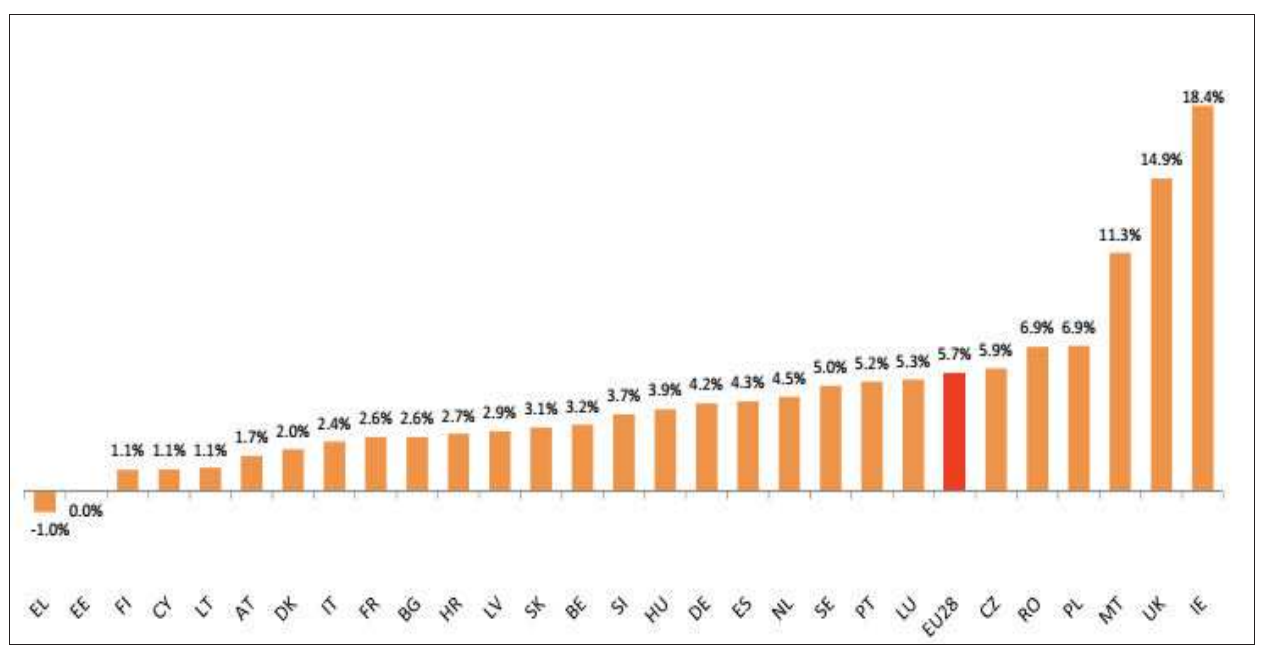

Fig. 2. EU SME value added annual growth by Member State, 2015

Source: Eurostat, National Statistical Offices and DIW Econ, refer the annexure-1 for acronym.

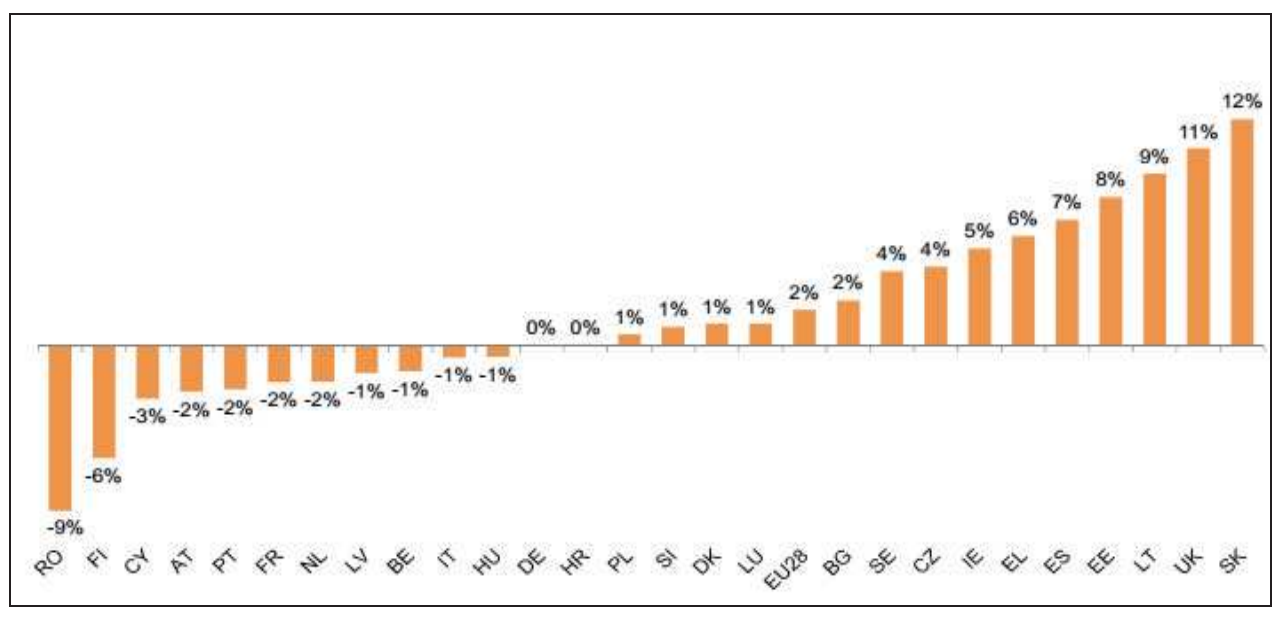

Fig. 3. SME employment growth in the high-tech sector by Member State, 2015

Source: Eurostat, National Statistical Offices and DIW Econ, refer the annexure-1 for acronym. 
Figure 2 demonstrates that the value added growth percentage in Ireland, the UK, and Malta was $18.4 \%, 14.9 \%$, and $11.4 \%$ respectively. In the cases of Ireland and Malta, the strong growth in SME value added reflects strong economy-wide growth. According to the European Union, this growth is shown in 'real estate' and 'professional, scientific and technical activities' sectors in Malta while in the case of the UK, the strong growth in value added reflects the sharp uptick of $14.9 \%$ in 2015 . The next highest growth rate after the top three is $6.9 \%$, recorded by Poland. Therefore, the growth in these three countries was considerably higher than across the rest of the EU28. Hungary has 3.9\% average growth, which is less than the average growth of $5.7 \%$ of the EU28. In general, the 'manufacturing', 'wholesale and retail trade' and 'other' sectors contributed more to the growth of SMEs and contributed in value added in the non-financial business sector across Member States.

From 2008 to 2013, microindustries contributed more in the SMEs sector; in Hungary, around 489,765 enterprises contributed to SMEs' growth rate. The average percentage of microindustries share is $94.1 \%$, which is greater than the average EU28 member state's of $92.8 \%$. The contribution of small industries is lower $-4.9 \%$ compared to the EU28 average of $6 \%$. Hungary has more microindustries but it contributes less in economic value added compared to the average EU28 figure. Hungary's share is $18.1 \%$, while EU28 contribute $21.2 \%$ in economic value added.

Table 2. Some short figures about Hungary's SMEs

\begin{tabular}{|c|c|c|c|c|c|c|c|c|c|}
\hline \multirow[t]{3}{*}{ Class size } & \multicolumn{3}{|c|}{ Number of enterprises } & \multicolumn{3}{|c|}{ Number of persons employed } & \multicolumn{3}{|c|}{ Value added } \\
\hline & \multicolumn{2}{|c|}{ Hungary } & \multirow{2}{*}{$\begin{array}{r}\text { EU28 } \\
\text { Share }\end{array}$} & \multicolumn{2}{|c|}{ Hungary } & \multirow{2}{*}{$\begin{array}{c}\text { EU28 } \\
\text { Share }\end{array}$} & \multicolumn{2}{|c|}{ Hungary } & \multirow{2}{*}{$\begin{array}{r}\text { EU28 } \\
\text { Share }\end{array}$} \\
\hline & Number & Share & & Number & Share & & Billion $€$ & Share & \\
\hline Micro & 489767 & $94.1 \%$ & $92.8 \%$ & 861275 & $34.4 \%$ & $29.5 \%$ & 9.6 & $18.1 \%$ & $21.2 \%$ \\
\hline Small & 25750 & $4.9 \%$ & $6.0 \%$ & 479997 & $19.2 \%$ & $20.2 \%$ & 8.6 & $16.3 \%$ & $18.0 \%$ \\
\hline $\begin{array}{l}\text { Medium- } \\
\text { sized }\end{array}$ & 4131 & $0.8 \%$ & $1.0 \%$ & 404644 & $16.2 \%$ & $17.0 \%$ & 9.5 & $18.0 \%$ & $18.2 \%$ \\
\hline SMEs & 519648 & $99.8 \%$ & $99.8 \%$ & 1745916 & $69.7 \%$ & $66.8 \%$ & 27.7 & $52.5 \%$ & $57.4 \%$ \\
\hline Large & 877 & $0.2 \%$ & $0.2 \%$ & 757678 & $30.3 \%$ & $33.2 \%$ & 25.1 & $47.5 \%$ & $42.6 \%$ \\
\hline Total & 520525 & $100.0 \%$ & $100.0 \%$ & 2503594 & $100.0 \%$ & $100.0 \%$ & 52.9 & $100.0 \%$ & $100.0 \%$ \\
\hline
\end{tabular}

Source: SBA Hungary fact sheet 2016.

Technology-intensive industries including high-tech SMEs have grown rapidly in the 21 st century. Technology-intensive companies in these industries need employees with both the technical and managerial leadership skills to ensure their success in this sector of SMEs. In the technology-intensive sector, certain member states experienced particularly high SME employment growth including Lithuania (9\%), Slovakia (12\%), and the UK $(11 \%)$. On the other hand, Hungary has $-1 \%$ growth rate. The overall average of EU28 was positive $1 \%$ growth in member states. In total, seven member states posted employment growth of $5 \%$ or more in 2015. 


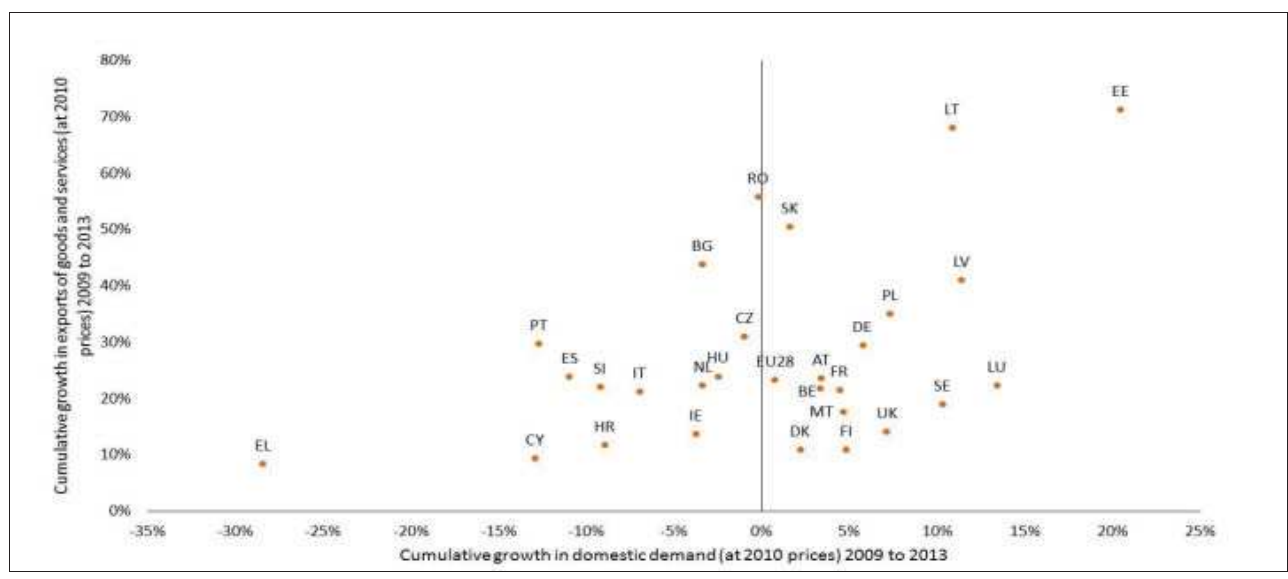

Fig. 4. Cumulative growth in final domestic demand (at 2010 prices) and exports of goods and services (at 2010 prices), 2009-2013

Source: Ameco 2015, refer the annexure-1 for acronym.

Domestic demand and exports that stimulated SMEs' growth have shown the economy in an optimistic way. Another reason for optimism in the economy is the slow economic recovery in EU28 member states. Hungary shows more than $20 \%$ of cumulative growth in the export of goods and services. Four countries (EE, LT, SK and RO) showed cumulative growth in exports of goods and services (at constant prices) of 50\% and more over the period from 2009 to 2013. Five countries (BG, CZ, LV, PL and PT) posted cumulative export growth (at constant prices) of $30 \%$ to $49 \%$ over the same period. Ten countries (AT, $\mathrm{BE}, \mathrm{DE}, \mathrm{FR}, \mathrm{ES}, \mathrm{HU}, \mathrm{IT}, \mathrm{LU}, \mathrm{NL}$ and SL) experienced cumulative export growth (at constant prices) of $20 \%$ to $39 \%$. Seven countries (DK, FI, HR, IR, MT, SE and UK) showed growth in exports of goods and services (at constant prices) of $10 \%$ to $19 \%$. Only two member states (CY and EL) posted export growth (at constant prices) of less than 10\%.

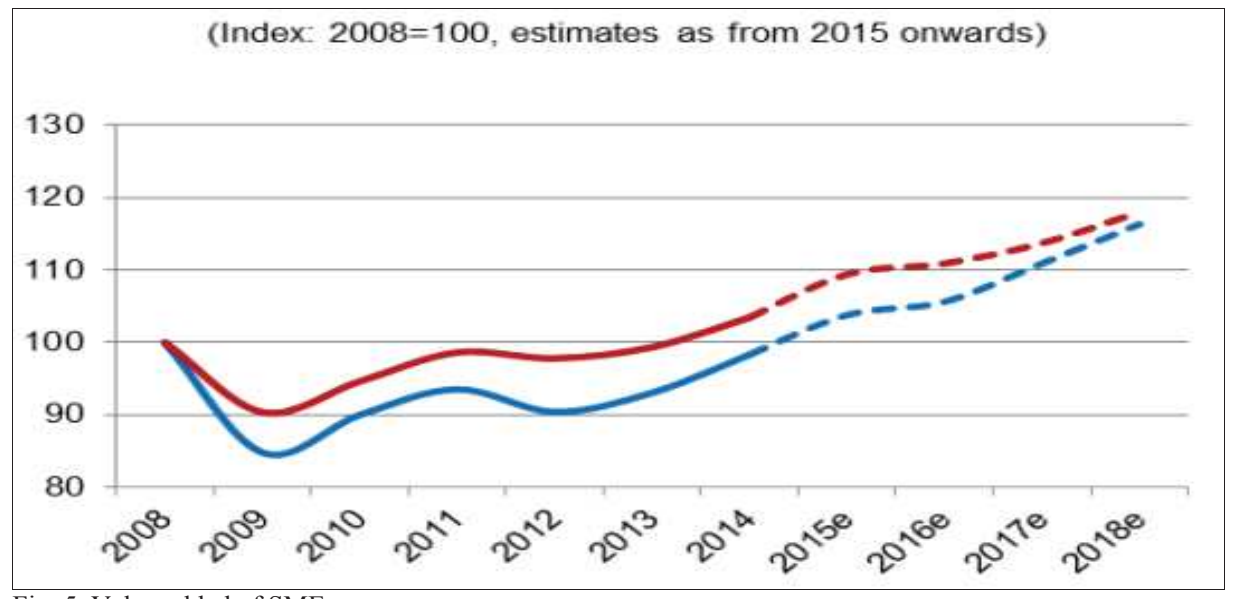

Fig. 5. Value added of SMEs

Source: SBA Hungary fact sheet 2017. 
Finance plays the major role in the development of SMEs. The funding scheme is replaced by a market-based lending scheme. Figure 6 shows that Hungarian SMEs are lagging behind as far as the production of EVA is concerned compared to the rest of Europe because of the lack of highly-skilled workers in high-tech sectors, bad financing availability and entrepreneur skills. Increasing the productivity of SMEs requires more entrepreneurs and skilled labour.

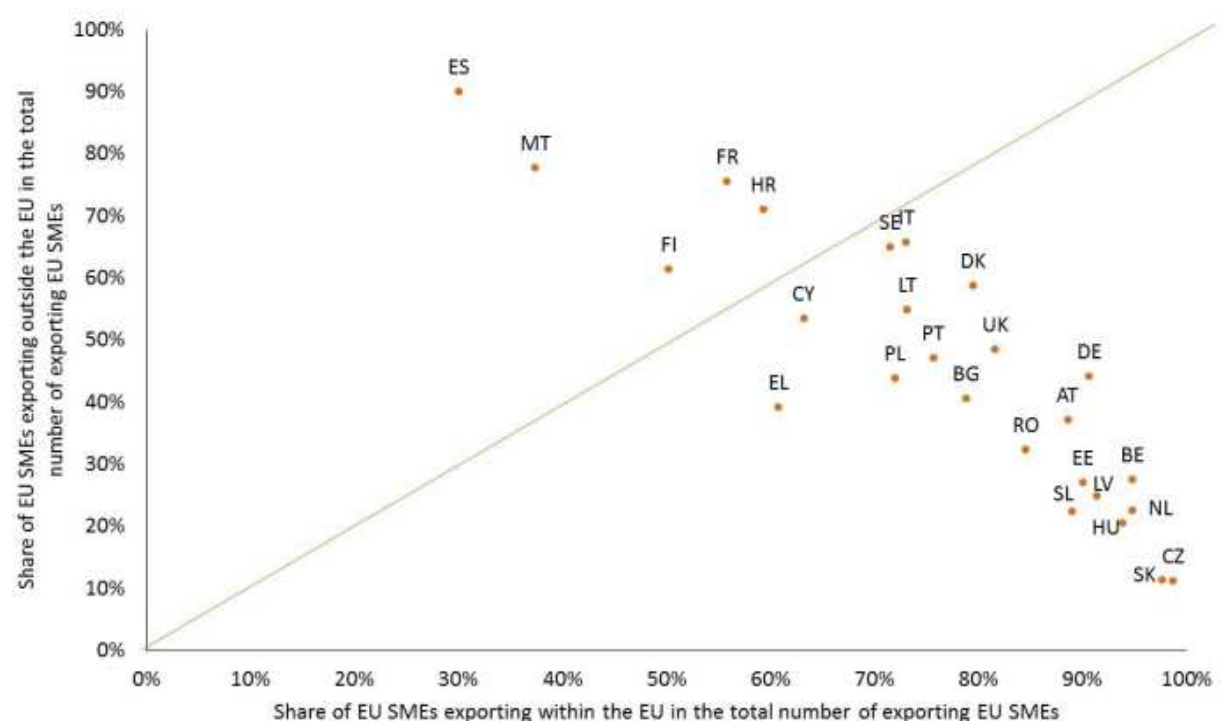

Fig. 6. Percentage of SMEs exporting inside the EU and outside the EU by EU Member State in 2013

Source: Eurostat, London Economics 2015, refer the annexure-1 for acronym.

As demonstrated in Figure 6, some of the EU28 members export more outside Europe. Estonia exports more than $90 \%$ outside Europe. Hungary exports more than $90 \%$ of goods to the EU28 members states. CZ, SK and NL are top of the list as far as exporting goods within the EU28 members states is concerned.

\section{Methodology and variable selection}

EVA is a useful tool to measure the performance management of SMEs. When EVA concurs with business practice, it influences the firm's result (Moujib Bahri at al, 2010). EVA was analyzed as a useful tool for SMEs performance management. The study indicated that some business has direct impact on EVA, while some practice found EVA insignificant.

Employees of different companies were asked 16 questions. A total of 65 samples were collected for research. A standard sample should be large enough in number to perform the factor analysis. In this research, the Kaiser-Meyer-Olkin value is 0.577 , which is greater than 0.50 . Thus, we can say that sampling in this research is adequate to perform the factor analysis. Sixteen variables are divided into four EVA components and each economic value component is explained by four questions asked during the survey. The 
first two questions are general variables. Questions 3-18 represent variables from V1-V16. EVA components were divided into four different groups of elements: production and equipment, material management, finance and capital as well as sales and purchase. These four variables created economic value added for collected SME samples. SPSS 25.0 is used to analyze the expletory factor analyses.

\section{Result analysis and discussion}

KMO measures the sampling adequacy, which should be more than 0.5 for a satisfactory factor analysis. Kaiser (1974) recommends 0.5 as the minimum value to analyse research. In this research, the Kaiser-Meyer-Olkin measure of sampling adequacy is 0.577 , which is sufficient for the performance. Significant value is 0.000 . Bartlett's test of sphericity degree of freedom is 120 .

Table 3. Total variance explained

\begin{tabular}{c|ccc}
\hline \multirow{2}{*}{ Component } & Total & Initial Eigenvalues & \\
& \% of Variance & Cumulative \% \\
\hline 1 & 4.391 & 27.442 & 27.442 \\
2 & 1.800 & 11.248 & 38.691 \\
3 & 1.699 & 10.618 & 49.309 \\
4 & 1.292 & 8.075 & 57.384 \\
6 & 1.149 & 7.178 & 64.562 \\
\hline
\end{tabular}

Source: own research.

Table 3 shows the extracted component variables. The 70.859 percent of variance is explained by the sixth component. The weightage of the first component is 27.442 , which contains twelve variables. Variables V4 and V12 have negative contribution in the first extracted component. These variables explain the maintaining and repairing of assets. The further component is cumulative with the other component. Thus, each component has impact on another (see Table 3 and Annex 2 for explanation). Entrepreneur skill and finance have the major impact. In other words, to achieve high growth in SMEs in the Somogy region, policy makers have to solve these two problems and create policies that focus on finance and the high skill development problem. The first component variable is related to the finance and skill condition. To achieve SMEs growth, the situation of finance and high skill development availability in the Somogy county region has to improve. 
Table 4. Commonalties and principal component analysis

\begin{tabular}{|c|c|c|c|c|c|c|c|}
\hline \multirow[b]{2}{*}{ Variable } & \multirow{2}{*}{$\begin{array}{c}{ }^{\mathrm{a}} \text { Commonalties } \\
\text { Extraction }\end{array}$} & \multicolumn{6}{|c|}{${ }^{\mathrm{b}}$ Component } \\
\hline & & 1 & 2 & 3 & 4 & 5 & 6 \\
\hline V1 & .802 & .772 & & & & & \\
\hline $\mathrm{V} 2$ & .625 & .713 & & -.315 & & & \\
\hline V3 & .727 & .710 & & & -.374 & & \\
\hline V4 & .628 & -.624 & .338 & & & & \\
\hline V5 & .670 & .613 & .462 & & & & \\
\hline V6 & .760 & .609 & & .374 & -.311 & .367 & \\
\hline V7 & .916 & .602 & & -.546 & & & \\
\hline V8 & .767 & .578 & .490 & & & -.408 & \\
\hline V9 & .669 & .516 & -.365 & & & & \\
\hline V10 & .767 & & -.678 & & -.332 & & \\
\hline V11 & .756 & .314 & -.465 & .519 & & & \\
\hline V12 & .718 & -.383 & .388 & -.406 & .348 & .369 & \\
\hline V13 & .642 & & & .463 & .672 & & \\
\hline V14 & .752 & & & .485 & & .521 & -.527 \\
\hline V15 & .483 & .463 & & & & .390 & .508 \\
\hline V16 & .652 & & & & .451 & & .504 \\
\hline
\end{tabular}

a. Extraction Method: Principal Component Analysis. b Extraction Method: Principal Component Analysis.

Source: own research.

As shown in Table 4, commonalties for all the variables are above 0.45 , so all variables are sufficient to contribute to research. The commonalties of the seventh variable are the highest among the other variables. The seventh variable is related to the company's effort to get the finance. Finance is the most important variable for Somogy county SMEs. External finance is the main factor preventing the progress of SMEs growth. This is possibly due to the asymmetric information availability (Kim, 1999). The second variable which considerably affects the SMEs industry is the lack of experienced labour. As seen from Figure 4, employment in Hungary's high-tech sector is negative.

Table 4 demonstrates that, in the component matrix, six variables are extracted out of sixteen variables. Variables V1, V2, and V3 are contributed $0.772,0.713$ and 0.710 respectively. The variable value lower than 0.30 is absent from the table. Variables V1, V2 and V3 are related to the skill in the region. Logistic supply and support is dominant in the second component.

\section{Conclusions}

EVA is used as a performance management tool to create value added for the shareholder. However, it does not determine the mindset of the organization, which is another critical determinant measuring future growth. The organization's mindset is important to understand future growth. EVA is useful for company labelling but it is not applicable to the labour and skill conditions and productivity. It gives an overview to 
investors of how the organization will behave in the future and whether the business has learnt something from the past mistakes. Hungary's SMEs are experiencing the lack of financing, entrepreneurs and highly-skilled labour. For SMEs to have a progressive future in Europe, another external source of finance and symmetric information about the financial condition of SMEs are necessary. Otherwise, the bank should have to ensure the symmetric information for a documentation file for the financing process of SMEs. A good EVA profile creates good market value. In this research, the results reveal that finance, skilled labour and entrepreneurship are the main determinants which positively influence EVA growth. Finance has the dominant part for the Somogy county region SMEs, which positively affects the other determinants of EVA. A positive approach to providing finance improves the condition of another determinant. Research revealed that a positive approach towards the investor and good, experienced employees is the main role. These key elements are necessary for the growth of SMEs.

\section{References}

Bahri, M., St-Pierre, J., Sakka, O. (2010). Economic value added:a useful tool for SME performance management. International Journal of Productivity and Performance Management, 60(6), 603-621.

Bartel, A. (1994). Productivity gains from the implementation of employee training programs. Industrial Relations, 33(4), 411-425.

Garengo, P., Biazzo, S. Bititci, U.S. (2005). Performance measurement systems in SMEs:a review for a research agenda. International Journal of Management Reviews, 7(1), 25-47.

Girotra, A., Yadav, S.S. (2001). Economic Value Added (EVA): A new flexible tool for measuring corporate performance. Global Journal of Flexible Systems Management, 2(1), 7-18.

Günther, T., Landrock, B., Muche T. (2000). Genwing versus Unternehmenswertorientierte performance - Eine Empirische Untersuchung auf Basis der Korrelation von Kapitalmarktrenditen für die Deutsche DAX-100 Unternehmen (Profit versus Value Based Performance Measures. An Empirical Investigation Based on the Correlation with Capital Market for German DAX-100 Companies). Controlling, 1(2), 69-75, 2(3), $129-134$.

Hussein, M., Gunasekaran, A., Laitinen, E.K. (1998). Management accounting system in Finnish service firms. Technovation, 18, 57-67

Petrescu, S., Apostol, C. (2009). Value Creation Analysis. Economic Value Added. Theoretical and Applied Economics, 5 (sup.), 118-123.

Porter, M.Y., Kramer, M.K. (2002). The competitive advantage of corporate philanthropy. Harvard Business Review, 80(12), 55-69.

Sharma, A.K., Kumar, S. (2010). Economic Value Added (EVA) - Literature Review. International Journal of Economics and Finance, 2(2), pp. 200-221.

Stern, J.M., Stewart, G.B. and Chew, D.H. (1998). "The EVA financial management system”, The Revolution in Corporate Finance, 3rd ed., Blackwell Publishers, Oxford.

Stewart, G.B. (1990). The Quest for Value: the EVA management guide, Harper Business, New York.

Szeleny, I. (1988). Socialist Entrepreneurs. Embourgeoisement in Rural Hungary. Madison, WI: University of Wisconsin Press.

Kim, J. (1999). The relaxation of financing constraints by the initial public offering of small manufacturing firms. Small Business Economics, 12(3), 191-202.

For citation:

Singh D., Gál Z., Huseynov R., Wojtaszek M. (2018). Determining the Performance Measurement of SME from Economic Value Added: Study on Hungary, Somogy County. Problems of World Agriculture, 18(2), 270-279; DOI: 10.22630/PRS.2018.18.2.54 